\title{
A Brief Overview on Active Air Sampling Procedure for Environment Monitoring
}

\author{
Juhi Rastogi ${ }^{1}$, Faiz Hashmi ${ }^{2}$ \\ ${ }^{1}$ QC Microbiologist, Nexgen Scientific, Baddi, Himachal Pradesh, India \\ ${ }^{2}$ QC Microbiologist, Scott-Edil Pharmacia, Baddi, Himachal Pradesh, India
}

\begin{abstract}
How to cite this paper: Juhi Rastogi | Faiz Hashmi "A Brief Overview on Active Air Sampling Procedure for Environment Monitoring" Published in International Journal of Trend in Scientific Research and Development (ijtsrd), ISSN: 24566470, Volume-3 | Issue-3 , April 2019, pp.732-736, URL: http://www.ijtsrd.co $\mathrm{m} /$ papers/ijtsrd229 87.pdf

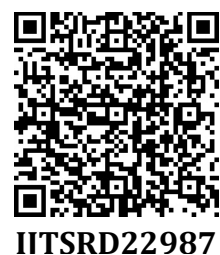

Copyright (C) 2019 by author(s) and International Journal of Trend in Scientific Research and Development Journal. This is an Open Access article distributed under the terms of the Creative Commons

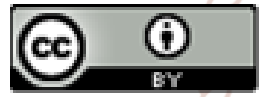
Attribution License (CC BY 4.0) (http://creativecommons.org/licenses/ by/4.0)

\section{INTRODUCTION}

Active Air Sampling for Environment Monitoring is performed in the pharmaceutical manufacturing plants. The purpose here is to monitor the contamination present in the environment which ultimately causes contaminate in the medicines i.e. being manufactured in specified areas. The contaminants can be non-viable particles and viable particles as well.

Active Air sampling is done by microbiologist in the production \& manufacturing area using the equipment known as 'Air Sampler'. A media plate of SCDA (SoybeanCasein Digest Agar) which is prepared under the sterile condition by the microbiologist. The media plate is then allowed to adjust under the 'Air Sampler hood' and then it is used for sampling purpose. Air sampler captures 1000L air per 10 minutes in a 1 cubic meter of volume and therefore air sampling is thus performed in the middle of the surrounding area. The sampled plate is then incubated and after the required incubation, the plate is thus analyzed to determine whether our manufacturing area meets the level of expected counts or is it crosses the required limit; and, on this basis the reporting is thus generated on a regular basis, weekly basis, monthly basis or twice a month.

\section{ABSTRACT}

In this paper, we are going to discuss the 'Active Air Sampling procedure for EM'. EM stands for Environment Monitoring. Environment monitoring is performed in the pharmaceutical manufacturing plants to monitor the contamination of ( Viable particle count can be observed plate \& swab test), and Personnel Monitoring method'. Non-viable particles are Active Air sampling is performed by microbiologist in the production \& manufacturing area using the equipment known as 'Air Sampler'. A media plate of SCDA (Soybean-Casein Digest Agar) prepared under sterile condition by the microbiologist. The media plate is then allowed to adjust under the 'Air Sampler and then it is used for sampling purpose. Air sampler captures 1000L air thus performed in the incubated, and after then the required incubation is provided, and the plate is expected counts or it crosses the required limit; and, on this basis, the reporting is thus generated on regular basis.

KEYWORDS: Environment Monitoring, Clean Room, Grades and their respective limits, Checkpoints of Media, Air Sampler and its operation, Incubation of the sampled plates, Trend chart analysis

\section{ENVIRONMENT MONITORING}

Environment Monitoring is the monitoring of surroundings in the production and manufacturing areas. EM is performed by various procedures, those are:

\section{Settle Plate Method:}

The $90 \mathrm{~mm}$ Petri plates are being prepared with $20 \mathrm{ml}-25 \mathrm{ml}$ of SCDA (Soybean casein digest agar), after the preincubation of 24 to 48 hours the Petri plates are allowed to be exposed for the 4 hours in the manufacturing area and then it is incubated at $20^{\circ} \mathrm{C}-25^{\circ} \mathrm{C}$ for 72 hours and observation is being recorded. Later the same plate is then incubated at $30^{\circ} \mathrm{C}-35^{\circ} \mathrm{C}$ for 48 hours and later the observation is being recorded.

\section{$>$ Active Air Sampling Method:}

The $90 \mathrm{~mm}$ Petri plates are being prepared with $20 \mathrm{ml}-25 \mathrm{ml}$ of SCDA (Soybean casein digest agar), after the preincubation of 24 hours the Petri plates are allowed for sampling and the Active Air Sampling procedure is to be started and to be continued up to 10 minutes or as per the time validated by each industry and then it is incubated at $20^{\circ} \mathrm{C}-25^{\circ} \mathrm{C}$ for 72 hours and observation is being recorded. Later the same plate is then incubated at $30^{\circ} \mathrm{C}-35^{\circ} \mathrm{C}$ for 48 hours and later the observation is being recorded. 


\section{$>$ Surface Monitoring methods:}

The surface monitoring procedure is performed to monitor the contaminants which stick to the surface of the working machine, laminar air flows, conveyor belts, door surface, floor surface, window glass wall surface. Then it is incubated at $20^{\circ} \mathrm{C}-25^{\circ} \mathrm{C}$ for 72 hours and observation is being recorded. Later the same plate is then incubated at $30^{\circ} \mathrm{C}-35^{\circ} \mathrm{C}$ for 48 hours and later the observation is being recorded.

Surface Monitoring is performed by the following two ways:

- Contact Plate Method:

The 55mm Petri plates are being prepared with $10 \mathrm{ml}$ $12 \mathrm{ml}$ of DNA (De-Engley Neutralizing Agar), after the pre-incubation of $24-48$ hours, the Petri plates are allowed to get in contact with the working machine, laminar air flows, conveyor belts, door surface, floor surface, window glass wall surface, etc. Then it is incubated at $20^{\circ} \mathrm{C}-25^{\circ} \mathrm{C}$ for 72 hours and observation is being recorded. Later the same plate is then incubated at $30^{\circ} \mathrm{C}-35^{\circ} \mathrm{C}$ for 48 hours and later the observation is being recorded.

- Swab Test Method:

Normal saline is used for this purpose. Swab sticks are dipped in normal saline in the swab collection tubes and this configuration is used for surface monitoring by swab test. All those locations where sample collection by the contact plate is not possible, swab test are then performed for all those locations, like a hopper, LAF corners, door handle wall corners, etc. The collected samples are then is being solidified by SCDA (Soybean casein digest agar) via pour plate techniques. Then it is incubated at $20^{\circ} \mathrm{C}-25^{\circ} \mathrm{C}$ for 72 hours and observation is being recorded. Later the same plate is then incubated at $30^{\circ} \mathrm{C}-35^{\circ} \mathrm{C}$ for 48 -hour sand later the observation is being recorded.

\section{Personnel Monitoring Method:}

The $55 \mathrm{~mm}$ Petri plates are being prepared with $10 \mathrm{ml}-12 \mathrm{ml}$ of DNA (De-Engley Neutralizing Agar), after the preincubation of $24-48$ hours the Petri plates are allowed to get in contact with the personnel working in the manufacturing area. The contact plate is being taken from various locations like forehead, chest, armpits, elbows, booties, and fingers. Then it is incubated at $20^{\circ} \mathrm{C}-25^{\circ} \mathrm{C}$ for 72 hours and observation is being recorded. Later the same plate is then incubated at $30^{\circ} \mathrm{C}-35^{\circ} \mathrm{C}$ for 48 hours and later the observation is being recorded.

\section{CLEAN ROOM AND ITS CLASSIFICATION}

A cleanroom is a facility ordinarily utilized as a part of specialized industrial production or scientific research, including the manufacture of pharmaceutical items and microprocessors. Cleanrooms are designed to maintain extremely low levels of particulates, such as dust, airborne organisms, or vaporized particles. Cleanrooms typically have a cleanliness level quantified by the number of particles per cubic meter at a predetermined molecule measure. The atmosphere outdoor air in a typical urban area contains $35,000,000$ particles for each cubic meter in the size range $0.5 \mu \mathrm{m}$ and bigger in measurement, equivalent to an ISO 9 cleanroom, while by comparison an ISO 1 cleanroom permits no particles in that size range and just 12 particles for each cubic meter of $0.3 \mu \mathrm{m}$ and smaller.

Table 01: The Area Classification of Inject-able Plants in general

\begin{tabular}{|c|c|}
\hline Room name & Grade \\
\hline Change Room-I of filling area 56,6170 & Grade D (ISO -8) \\
\hline Change Room-I of Manufacturing area & Grade D (ISO -8) \\
\hline Change Room-I of Sampling area & Grade D ( ISO -8) \\
\hline Change Room-II of sampling area & Grade C ( ISO -7) \\
\hline Change Room-II of dispensing area & Grade C ( ISO -7) \\
\hline Change Room-II of Manufacturing room & Grade C ( ISO -7) \\
\hline Change Room-II of washing room & Grade C ( ISO -7) \\
\hline Change Room-II of preparation room & Grade C ( ISO -7) \\
\hline Staging room & Grade B ( ISO -6) \\
\hline Cooling Zone & Grade B ( ISO -6) \\
\hline Filtration Room & Grade B ( ISO -6) \\
\hline Corridor area of filling & Grade B ( ISO -6) \\
\hline Blending room & Grade B ( ISO -6) \\
\hline Mobile LAF & Grade A ( ISO -5) \\
\hline Filtration LAF & Grade A ( ISO -5) \\
\hline Garment Cabinets & Grade A ( ISO -5) \\
\hline Passbox & Grade A ( ISO -5) \\
\hline RLAF & Grade A ( ISO -5) \\
\hline
\end{tabular}

GRADES AND THEIR RESPECTIVE LIMITS

Table 02: Limits According to EU guidelines

\begin{tabular}{|c|c|c|c|c|}
\hline Grade & $\begin{array}{c}\text { Active Air } \\
\text { Sampling }\end{array}$ & $\begin{array}{c}\text { Settle Plate }(90 \mathrm{~mm}), \\
\text { cfu/4hrs }\end{array}$ & $\begin{array}{c}\text { Contact Plate (55mm), } \\
\text { cfu/plate }\end{array}$ & $\begin{array}{c}\text { Glove print } 5 \text { fingers, } \\
\text { cfu/glove }\end{array}$ \\
\hline A & $<1$ & $<1$ & $<1$ & $<1$ \\
\hline B & 10 & 5 & 5 & 5 \\
\hline C & 100 & 50 & 25 & n.a. \\
\hline D & 200 & 100 & 50 & n.a. \\
\hline \multicolumn{4}{|c|}{ According to EU guidelines } \\
\hline
\end{tabular}


International Journal of Trend in Scientific Research and Development (IJTSRD) @ www.ijtsrd.com eISSN: 2456-6470

Table 03: Limits According to FDA guidance (2004)

\begin{tabular}{|c|c|c|c|}
\hline $\begin{array}{c}\text { Clean area classification } \\
(\mathbf{0 . 5} \boldsymbol{\mu m} \text { particles/ft3) }\end{array}$ & $\begin{array}{c}\text { Active Air } \\
\text { Sampling, cfu/m3 } 3\end{array}$ & $\begin{array}{c}\text { Settle Plate } \\
(\mathbf{9 0} \mathbf{m m}), \text { cfu/4hrs }\end{array}$ & $\begin{array}{c}\text { Glove Print 5 } \\
\text { fingers, cfu/glove }\end{array}$ \\
\hline 100 & ISO 5 & 1 & 1 \\
\hline 1000 & ISO 6 & 7 & 3 \\
\hline 10000 & ISO 7 & 10 & 5 \\
\hline 100000 & ISO 8 & 100 & 50 \\
\hline \multicolumn{4}{|r}{ According to FDA guidance (2004) } \\
\hline
\end{tabular}

Table 04: ISO 14644-1 Cleanroom Standards

\begin{tabular}{|c|c|c|c|c|c|c|c|}
\hline \multirow{2}{*}{ Class } & \multicolumn{6}{|c|}{ maximum particles $/ \mathrm{m}^{3}$} & \multirow{2}{*}{$\begin{array}{l}\text { FED STD 209E } \\
\text { equivalent }\end{array}$} \\
\hline & $>=0.1 \mu \mathrm{m}$ & $>=0.2 \mu \mathrm{m}$ & $>=0.3 \mu \mathrm{m}$ & $>=0.5 \mu \mathrm{m}$ & $>=1 \mu \mathrm{m}$ & $>=5 \mu \mathrm{m}$ & \\
\hline ISO 1 & 10 & 2 & & & & & \\
\hline ISO 2 & 100 & 24 & 10 & 4 & & & \\
\hline ISO 3 & 1,000 & 237 & 102 & 35 & 8 & & Class 1 \\
\hline ISO 4 & 10,000 & 2,370 & 1,020 & 352 & 83 & & Class 10 \\
\hline ISO 5 & 100,000 & 23,700 & 10,200 & 3,520 & 832 & 29 & Class 100 \\
\hline ISO 6 & $1,000,000$ & 237,000 & 102,000 & 35,200 & 8,320 & 293 & Class 1,000 \\
\hline ISO 7 & & & & 352,000 & 83,200 & 2,930 & Class 10,000 \\
\hline ISO 8 & & & & $3,520,000$ & 832,000 & 29,300 & Class 100,000 \\
\hline ISO 9 & & & & $35,200,000$ & $8,320,000$ & 293,000 & Room Air \\
\hline
\end{tabular}

Table 05: BS 5295 Cleanroom Standards

\begin{tabular}{|c|c|c|c|c|c|}
\hline & \multicolumn{5}{|c|}{ maximum particles $/ \mathrm{m}^{3}$} \\
\hline Class & $>=\mathbf{0 . 5} \mu \mathrm{m}$ & $>=1 \mu \mathrm{m}$ & $>=5 \mu \mathrm{m}$ & $>=\mathbf{1 0} \mu \mathrm{m}$ & $>=25 \mu \mathrm{m}$ \\
\hline Class 1 & 3,000 & & 0 & 0 & 0 \\
\hline Class 2 & 300,000 & & 2,000 & 30 & \\
\hline Class 3 & & $1,000,000$ & 20,000 & 4,000 & 300 \\
\hline Class 4 & & & 20,000 & 40,000 & 4,000 \\
\hline
\end{tabular}

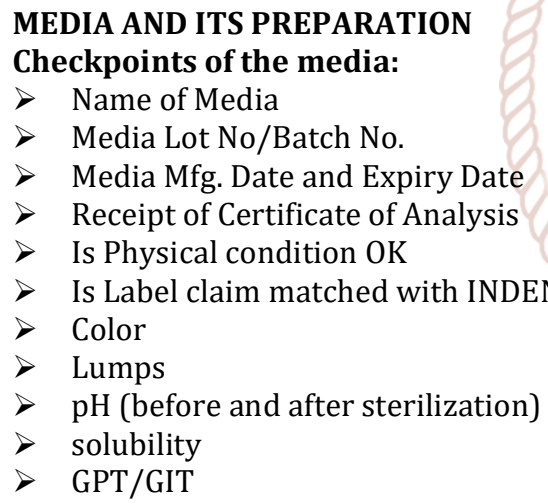

\section{Preparation of media}

The purified water are used for the media preparation. The quantity of dehydrated media required for the volume of media to be prepared is to be calculated. The calculated quantity of media on a calibrated weighing balance is to be weighed and then is transferred into the conical flask/ Bottle/ Tubes containing a small part of required water quantity. The remaining quantity of water is added into the conical flask/ Bottle/ Tubes. The media is then dissolved by swirling the flask or boil/heat the media (as per manufacturer recommendation if required) on a water bath or hot plate to dissolve completely. The $\mathrm{pH}$ of the unsterilized media is then checked and recorded the verified $\mathrm{pH}$ of the media. If the $\mathrm{pH}$ varies, it is then adjusted by the addition of $0.1 \mathrm{~N}$ Hydrochloric acid or $0.1 \mathrm{~N}$ Sodium hydroxide before sterilization so as to $\mathrm{pH}$ remains under limit after sterilization. If the $\mathrm{pH}$ of media is satisfactory then set the cotton plug in the flask / bottle / tube mouth. Before sterilization, chemical indicator shall be placed in the autoclave. The test tubes/Flask /Bottles shall be labeled with 3M tape with the name of the media lot No. The media is then sterilized in steam sterilizer by operating the autoclave standard process $1\left(121^{\circ} \mathrm{C}\right)$ \& standard process $2\left(115^{\circ} \mathrm{C}\right)$ for 20 minutes. For Heat Labile Media boil the media up to $80^{\circ} \mathrm{C}$ up to dissolved. The sterilized media is then unloaded from autoclave in the Cool Zone area. Allow the media to cool according the room temperature. Check the $\mathrm{pH}$ of sterilized media by taking a broth media tube.

\section{Preparation of Plates}

SCDA (1\% glycerol added) media is used for active air sampling. The media shall be prepared and autoclaved respectively. Approximately $15-20 \mathrm{ml}$ of liquefied SCDA ( $1 \%$ glycerol added) media is being under LAF and cooled up to $40^{\circ} \mathrm{C}-45^{\circ} \mathrm{C}$ in all the Petri plates required as per the exposure location. The Petri plates is then covered and the poured media is allowed to solidify. After the solidification, all media containing Petri plates are incubated for the purpose of pre-incubation in the incubator at $32.5^{\circ} \mathrm{C} \pm 2.5^{\circ} \mathrm{C}$ for $24-48$ hours in an inverted position for detecting any contamination during plate pouring operations. After 
International Journal of Trend in Scientific Research and Development (IJTSRD) @ www.ijtsrd.com eISSN: 2456-6470

the pre-incubation, examine all Petri plates for microbial growth. Petri plates without contamination and having no air bubbles shall be selected for active air sampling.

\section{Result Calculation}

Calculate the result as per the formula is given here.

Where;

$$
x-\frac{\operatorname{Pr} * 1000}{V}
$$

$\mathrm{X}=\mathrm{CFU} / \mathrm{m}^{3}$

$\mathrm{V}=$ Volume of air sampler

$\mathrm{r}=\mathrm{CFU}$ counted on $90 \mathrm{~mm}$ plate

$\operatorname{Pr}=$ Probable count obtained by positive hole correction against $\mathrm{r}$ value.

\section{AIR SAMPLER AND ITS OPERATION}

\section{Preparation of Air Sampler and its Accessories}

The Sterilized/ Depyrogenate hood and labeled Petri plates are to be kept in the hatch box as per requirement. The Air Sampler and hatch box are being carried into the aseptic area by mopping with $70 \%$ IPA.

\section{Working of Air Sampler:}

The pre-incubated sanitized labeled SCDA (1\% glycerol added) plate is being placed in the feeder cone circular clamp assembly in position. The air sampler is then placed in the area where air sampling is being done. The "ON" switch is then turned on which is provided on the back side of the air sampler which shows power "ON" by glowing lamp. The following procedure is then followed for the sampling purpose:

$>$ Initial display shall be observed.

$>$ Press "START ON" the control panel to obtain $1000 \mathrm{Ltr}$ air

$>$ Instrument shall be automatically OFF after sucking 1000 Ltr of air.

$>$ Then open the SS hood and remove the plate aseptically.

$>$ For next location, sanitize the stainless steel Hood and carry within air Sampler trolley.

Cover the plate with their upper lid then incubate for first 72 hours at $22.5^{\circ} \mathrm{C} \pm 2.5^{\circ} \mathrm{C}$ and further 48 hours at $32.5^{\circ} \mathrm{C} \pm 2.5^{\circ} \mathrm{C}$ for fungal and bacterial growth respectively.

\section{OBSERVATIONS}

Table 06: TAMC < Action limit or Alert limit signifies that the area is pass.

\begin{tabular}{|c|c|c|}
\hline \multicolumn{3}{|c|}{ Grade-B | Method: Active Air Sampling } \\
\hline Date & Observation after $72 \mathrm{hrs}$. & Observation after 48 hrs. \\
\hline $1 / 3 / 2019$ & $<1<0$ < $<10$ PIII & 1 \\
\hline $2 / 3 / 2019$ & $<1$ & 2 \\
\hline $3 / 3 / 2019$ & $<1$ & 0.1 \\
\hline $4 / 3 / 2019$ & $<1$ & 2 \\
\hline $5 / 3 / 2019$ & $<1 \quad-1$ & 1102 \\
\hline $6 / 3 / 2019$ & $D^{2}<1>7$ & 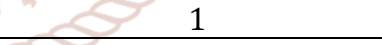 \\
\hline $7 / 3 / 2019$ & $<1$ nn & $S$ \\
\hline
\end{tabular}

Table 07: TAMC > Action limit or Alert limit signifies that the area is fail.

\begin{tabular}{|c|c|c|}
\hline \multicolumn{3}{|c|}{ Grade-B | Method: Active Air Sampling } \\
\hline Date & Observation after $72 \mathrm{hrs}$. & Observation after $48 \mathrm{hrs}$. \\
\hline $1 / 3 / 2019$ & $<1$ & 2 \\
\hline $2 / 3 / 2019$ & $<1$ & 3 \\
\hline $3 / 3 / 2019$ & $<1$ & 4 \\
\hline $4 / 3 / 2019$ & $<1$ & 3 \\
\hline $5 / 3 / 2019$ & $<1$ & 2 \\
\hline $6 / 3 / 2019$ & $<1$ & 3 \\
\hline $7 / 3 / 2019$ & $<1$ & 3 \\
\hline
\end{tabular}

\section{TREND CHART ANALYTICAL DATA}

Table 08: TAMC < Action limit or Alert limit signifies that the area is pass.

\begin{tabular}{|c|l|l|l|l|l|l|l|}
\hline \multicolumn{8}{|c|}{ Demonstration of One week Trend Chart for Active Air Sampling in Grade-B Area } \\
\hline Date & $1 / 3 / 2019$ & $2 / 3 / 2019$ & $3 / 3 / 2019$ & $4 / 3 / 2019$ & $5 / 3 / 2019$ & $6 / 3 / 2019$ & $7 / 3 / 2019$ \\
\hline TAMC & 1 & 2 & 1 & 2 & 2 & 1 & 2 \\
\hline Limits & 10 & 10 & 10 & 10 & 10 & 10 & 10 \\
\hline Action Limits & 8 & 8 & 8 & 8 & 8 & 8 & 8 \\
\hline Alert Limits & 6 & 6 & 6 & 6 & 6 & 6 & 6 \\
\hline Minimum & \multicolumn{7}{|c|}{1} \\
\hline Maximum & \multicolumn{7}{|c|}{2} \\
\hline Average & \multicolumn{7}{|c|}{1 (1428571 } \\
\hline
\end{tabular}


Chart 01: TAMC < Action limit or Alert limit signifies that the area is pass.

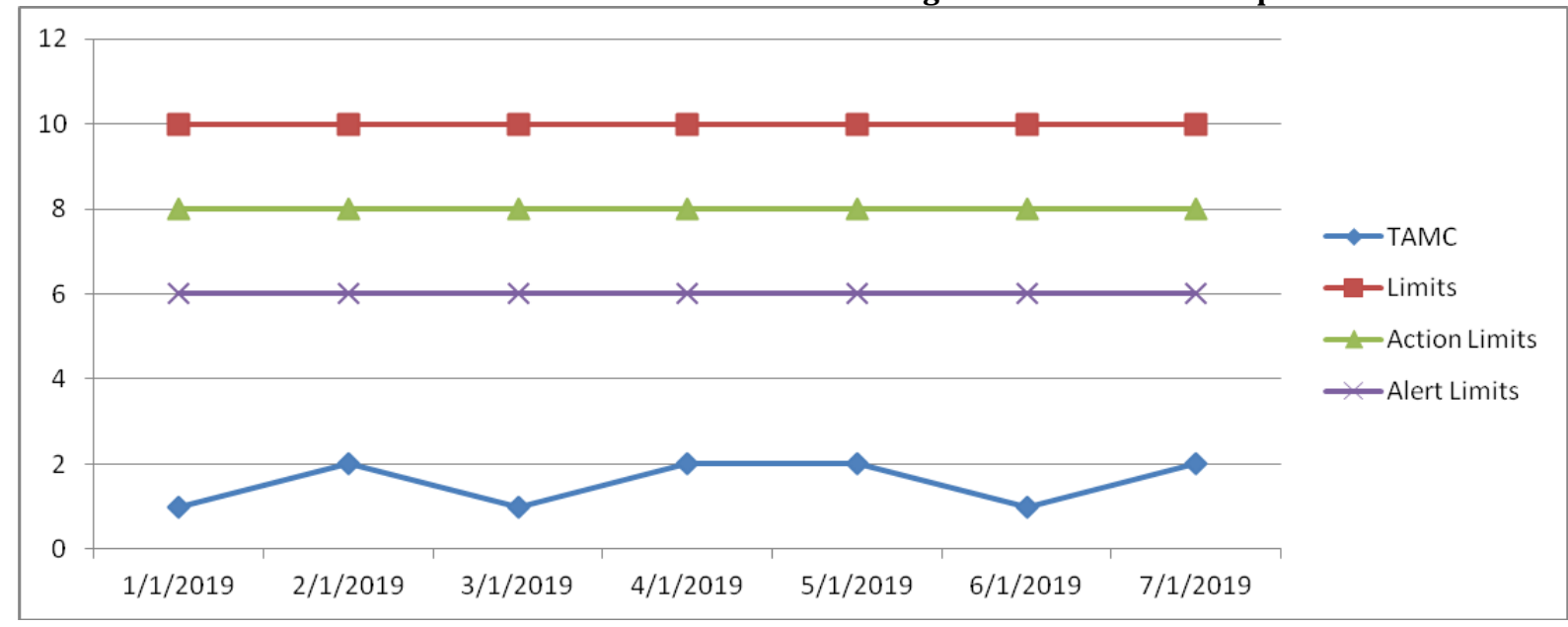

Table 09: TAMC > Action limit or Alert limit signifies that the area is fail.

Demonstration of One week Trend Chart for Active Air Sampling in Grade-B Area

\begin{tabular}{|c|c|c|c|c|c|c|c|}
\hline Date & $1 / 3 / 2019$ & $2 / 3 / 2019$ & $3 / 3 / 2019$ & $4 / 3 / 2019$ & $5 / 3 / 2019$ & $6 / 3 / 2019$ & $7 / 3 / 2019$ \\
\hline TAMC & 9 & 8 & 10 & 11 & 12 & 11 & 9 \\
\hline Limits & 10 & 10 & 10 & 10 & 10 & 10 & 10 \\
\hline Action Limits & 8 & 8 & 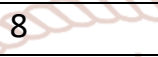 & 8 & 8 & 8 & 8 \\
\hline Alert Limits & 6 & 6 & $6 \cap 5 \mathrm{cll}$ & 6 & 6 & 6 & 6 \\
\hline \multicolumn{8}{|l|}{ Minimum } \\
\hline \multicolumn{8}{|l|}{ Maximum } \\
\hline Average & & 8 & 5 & 10 & $9 /$ & & \\
\hline
\end{tabular}

Chart 02: TAMC > Action limit or Alert limit signifies that the area is fail.

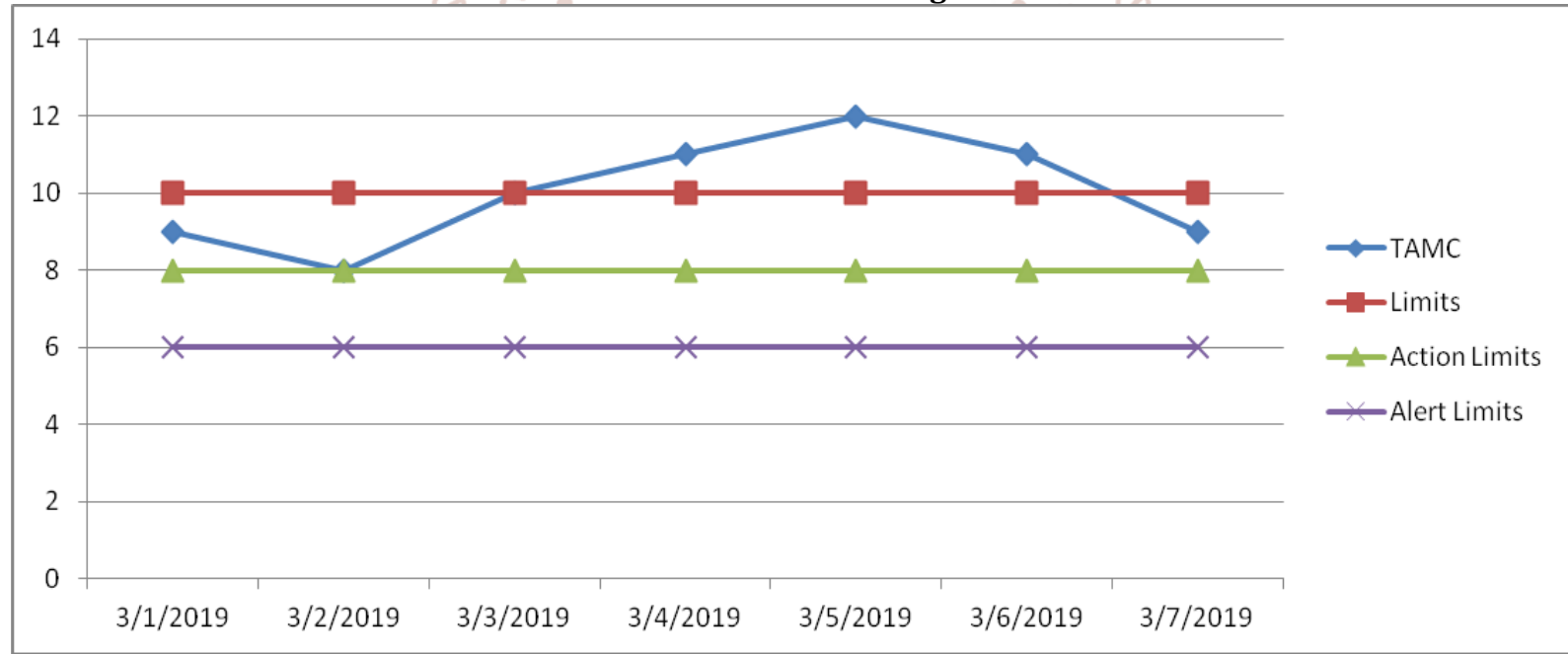

\section{REFERENCES}

[1] USP, "USP Microbiological Control and Monitoring of Aseptic Processing Environments," USP 35 vol. 1 2012a, 2012: pp. 697-707.

[2] Guidance for Industry - Sterile Drug Products Produced by Aseptic Processing - Current Good Manufacturing Practice, U.S. Food and Drug Administration, 2004

[3] "Manufacture of Sterile Medicinal Products" In EudraLex - The Rules Governing Medicinal Products in the European Union, Volume 4 EU Guidelines to Good Manufacturing Practice - Medicinal Products for Human and Veterinary Use - Annex 1: Manufacture of
Sterile Medicinal Products, European Commission, 2008

[4] Dalmaso, G., and Denoya, C. "Microbial Control and Monitoring in Aseptic Processing Cleanrooms" Controlled Environments (2015) http://www.cemag.us/articles/2015/01/microbialcontrol-and-monitoring-asepticprocessing-cleanrooms

[5] ISO International Standard 14644 Part 1, International Organization for Standardization, May 1999

[6] https://en.wikipedia.org/wiki/Cleanroom 